\title{
Accessory Transverse Foramina in the Cervical Spine: Incidence, Embryological Basis, Morphology and Surgical Importance
}

\author{
Servikal Omurgada Aksesuar Transvers Foramen: \\ Insidansi, Embriyolojik Temeli, Morfoloji ve Cerrahi Önemi
}

B.V. MURLIMANJU' ${ }^{1}$, Latha V. PRABHU ${ }^{1}$, K. SHILPA ${ }^{1}$, Rajalakshmi RAI ${ }^{1}$, K.V.N. DHANANJAYA², P.J. JIJI ${ }^{1}$

${ }_{1}^{1}$ Manipal University, Kasturba Medical College, Department of Anatomy, Mangalore (D.K.), India

${ }_{2}^{2}$ Manipal University, Kasturba Medical College, Department of Radiology, Mangalore (D.K.), India

Correspondence address: B.V.MURLIMANJU / E-mail: flutesnowmm@gmail.com

\begin{abstract}
AIM:To study the incidence of accessory foramina transversaria in cervical spine and to analyze them morphologically with emphasize on their embryological and surgical importance.

MATERIAL and METHODS: The study included 363 human cervical vertebrae which were procured from the bone collections of the Department of Anatomy. The foramen transversarium was observed macroscopically on both sides of all the vertebras, the accessory foramina were noted.

RESULTS: Out of 363 specimens, only 6 (1.6\%) vertebrae showed the accessory foramina. Among them 5 (1.4\%) vertebra had double foramina and only $1(0.3 \%)$ vertebra showed three foramina. Only $1(0.3 \%)$ vertebrae showed the foramen on both sides and the remaining $5(1.4 \%)$ had unilateral foramina. Among the unilateral, 4 were present on the right side and only 1 was on the left side. No vertebrae showed the absence of foramen transversarium.

CONCLUSION: The present study observed the accessory foramina transversarium in $1.6 \%$ of cases. The unilateral presence was more common than the bilateral. The surgical anatomy of these variations is important for the neurosurgeons and radiologists for interpreting the computed tomogram and magnetic resonance image scans. Their morphological knowledge is clinically important since the course of the vertebral artery may be distorted in such situations.
\end{abstract}

KEYWORDS: Accessory foramina, Cervical vertebra, Foramen transversarium

Öz

AMAÇ: Servikal omurgada aksesuar transvers foramen insidansını araştırmak ve, embriyolojik ve cerrahi önemini vurgulayarak morfolojik olarak bunları analiz etmek.

YÖNTEM ve GEREÇ: Çalışmaya Anatomi Anabilim Dalı kemik koleksiyonlarından satın alınmış 363 insan servikal omuru dahil edilmiştir. Tüm omurların her iki tarafında transvers foramenler makroskopik olarak gözlendi ve aksesuar foramenler kaydedildi.

BULGULAR: 363 spesimenin sadece 6'sında $(\% 1,6)$ omurlar aksesuar foramen gösterdi. Bunların içinde $5(\% 1,4)$ vertebrada çift foramen vardı ve sadece $1(\% 0,3)$ vertebra üç foramen gösterdi. Sadece $1(\% 0,3)$ omurda her iki foramen görünüyordu ve kalan $5(\% 1.4)$ tanesinde tek taraflı foramen vardı. Tek taraflı olanların, 4 tanesinde sağ tarafta ve sadece 1 tanesinde sol tarafta idi. Hiçbir omurga foramen transversarium yokluğu göstermedi.

SONUÇ: Bu çalışmada, olguların \%1,6'sında aksesuar foramina transversarium gözlendi. Tek taraflı varlığı iki taraflı olmasından daha sıktı. Bu varyasyonların cerrahi anatomisi beyin cerrahları ve radyologların bilgisayarlı tomografi ve manyetik rezonans görüntülerini yorumlamaları için önemlidir. Bunların morfolojik bilgileri klinik açıdan önemlidir çünkü bu durumlarda vertebral arterin gidişi değişebilir.

ANAHTAR SÖZCÜKLER: Aksesuar foramen, Servikal omur, Tranvers foramen 


\section{INTRODUCTION}

The foramen transversarium present on the transverse process of cervical vertebrae are known to transmit the vertebral artery, vertebral veins and sympathetic nerves (6). These foramina are known to exhibit variations with respect to the shape, size and sometimes are multiple or absent. Their etiology may be related to variations of the course of vertebral artery and is developmental (6). An accessory transverse foramen, posterior to and smaller than the primary foramen, may be found in the sixth vertebra, and less frequently in the adjacent vertebrae (2). Under such circumstances, the course of the vertebral artery may be distorted. The variations in number and size of foramina transversaria of cervical spine may be one of the causes for complaints like headache, migraine, and fainting attacks and are due to the compression of vertebral artery (4). Understanding the surgical anatomy of cervical spine is essential while performing the complex surgical procedures that involve the screw fixation. The osseous and vascular variations of cervical spine that place the vertebral artery at risk during surgical procedures have been identified (3).

The anatomical details of foramen transversarium variations are important to the clinicians and radiologists in interpreting $X$ ray and $C T$ scans (6). In the scientific literature, most of the anatomical and clinical studies have concentrated on the course and variant origins of the vertebral artery. There are only a very few reports available on the morphology of the accessory transverse foramina and their incidence. This was the stimulus for us to undertake this investigation. The objective of the present study was to find the incidence of accessory foramina transversaria in the cervical spine. The foramina were morphologically analyzed with an emphasis on their embryological basis and surgical importance.

\section{MATERIAL and METHODS}

The study included 363 human cervical vertebrae that were procured from the bone collections of the department of anatomy. Among the vertebra, 242 were typical cervical vertebra (C3, C4, C5 and C6) and 121 were atypical (49 atlases, 38 axes and 34 (C7) vertebra prominens). The age and sex of the bones were not known. The foramen transversaria were observed macroscopically in all vertebrae on both sides and the accessory foramina were noted. A 24 gauze needle was passed through the accessory foramina to confirm their patency. The vertebrae that had pathological changes were excluded from the present study. The data were collected on a standardized collection sheet. The variant vertebrae were photographed with the digital camera.

\section{RESULTS}

Out of 363 specimens, only 6 (1.6\%) vertebrae showed the accessory foramina. Among them 5 (1.4\%) vertebra had double foramina (Figures 1 and 2) and only 1 (0.3\%) vertebra showed three foramina (Figure 3). Only $1(0.3 \%)$ vertebrae showed the foramen on both sides (Figure 1) and the remaining 5 (1.4\%) had unilateral foramina (Figure 2). Among the unilateral cases,
4 were present on the right side and only 1 was on the left side. All the accessory foramina were observed in the lower vertebrae (C6 and C7). The accessory foramina transversaria were smaller than the regular foramina in all cases. There were no variations observed in the atlas and axis bones. No vertebrae showed absence of foramen transversarium.

\section{DISCUSSION}

The foramen transversarium is a result of the special formation of the cervical transverse processes. It is formed by the vestigial costal element fused to the body and the true transverse process of the vertebra. The vertebral vessels and nervous plexus are caught between these two bony parts. The foramen transversarium is closed laterally by the costotransverse bar, a thin plate of bone connecting the rib element to the original transverse process (14). The vertebral artery is developed from the fusion of longitudinal anastomoses that link the cervical intersegmental arteries, which branch off from the primitive dorsal aorta. These intersegmental arteries eventually regress, except for the seventh artery, which forms the proximal portion of the subclavian artery, including the beginning of the vertebral artery (8). Sim et al. (13) described that some portion of the primitive dorsal aorta may not regress along with the two intersegmental arteries which connect the vertebral artery. It is believed that this arrangement may lead to double origin and duplication of the vertebral artery. The duplication is thought to represent the failure of controlled regression of two intersegmental arteries and a segment of the primitive dorsal aorta. Bilateral occurrence of these failures is the etiology behind bilateral duplication of the vertebral artery (8). The triple foramina transversaria is a very unusual variation and seems to be the result of double rib bone element on the same side fusing to the original transverse process, resulting in unusual number of foramina. Therefore the vertebra with triple foramina transversaria shows two costal bars instead of one (14).

The vertebral arteries constitute one of the vascular components of the cervical region of the spinal column that ascend parallel to the spines through the transverse foramina of the upper six cervical vertebrae. They supply the cervical part of spinal cord, spinal ganglions, meninges and duramater in the posterior cranial fossa. It was reported that this artery enters the foramen transversarium of vertebra at C6 in $88 \%$ of cases, and C7 and C5 in only 5\% and 7\% of cases (10). The transverse foramen of the seventh cervical vertebra contains some branches of vessels and nerves as well as fibrous and adipose tissues (9). Since the vertebral vessels are the factors in the formation of the foramen transversarium, it can beassumed that variations in the presence and course of the vertebral vessels will manifest as variant foramen transversarium. In contrast, variations of the foramen transversarium can be useful in estimating the variations of the vessels. An absence of foramen transversarium could mean absence of the vertebral artery (14). A narrowing of the foramina indicates narrowness of the vessels and so on. But there are cases where 


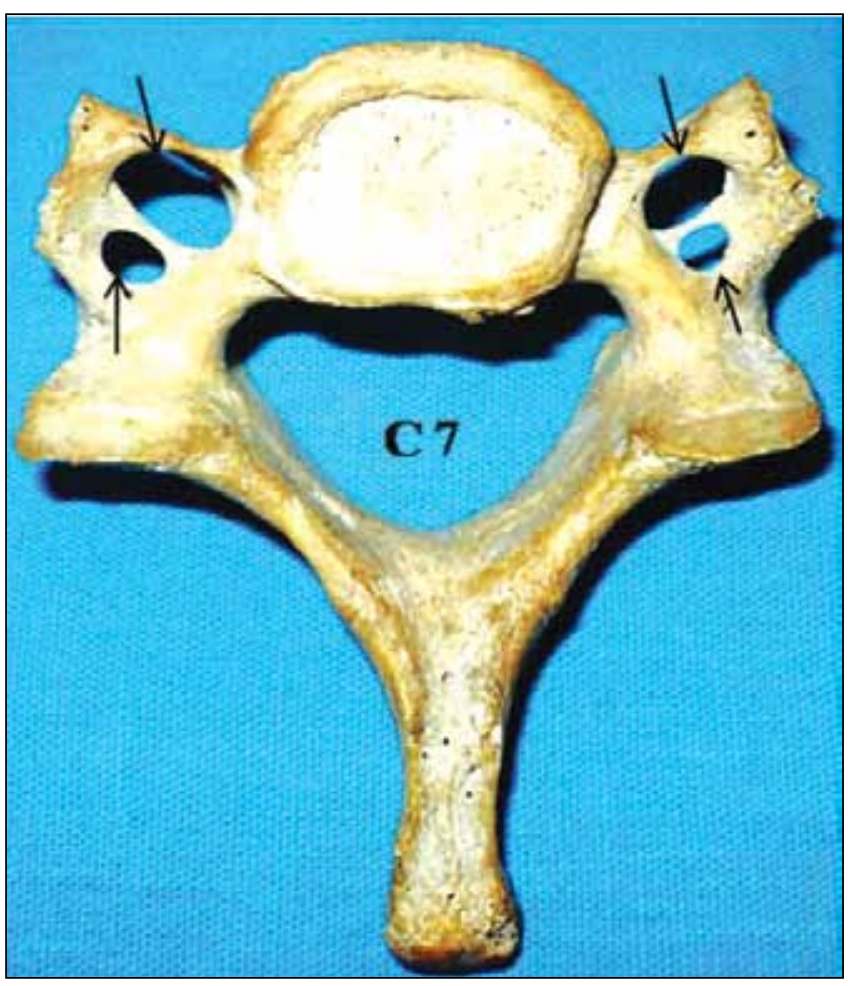

Figure 1: Photograph of C7 cervical spine (inferior view) showing the bilateral double foramina transversaria $(n=1,0.3 \%)$.

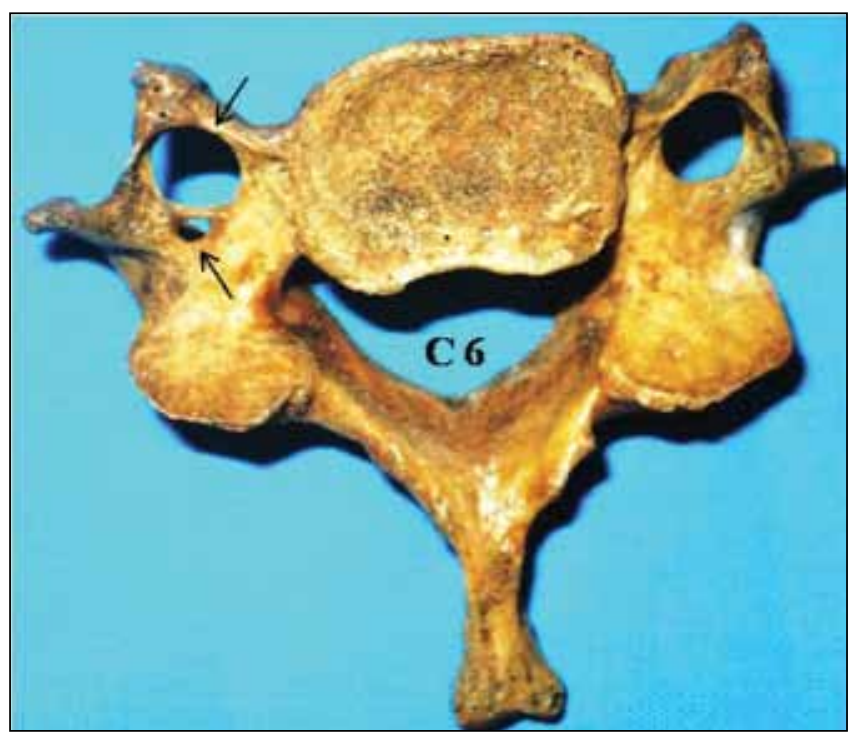

Figure 2: Photograph of C6 cervical spine (inferior view) showing the unilateral double foramina transversaria $(n=5,1.4 \%)$.

the vertebral artery runs along the transverse process and not through the foramen transversarium. This is very common in the lower cervical vertebrae. Instead of entering to the sixth foramen transversarium, the artery may start to enter the foramen at higher levels. The greatest variability in foramen transversarium is found in the seventh cervical spine (14).

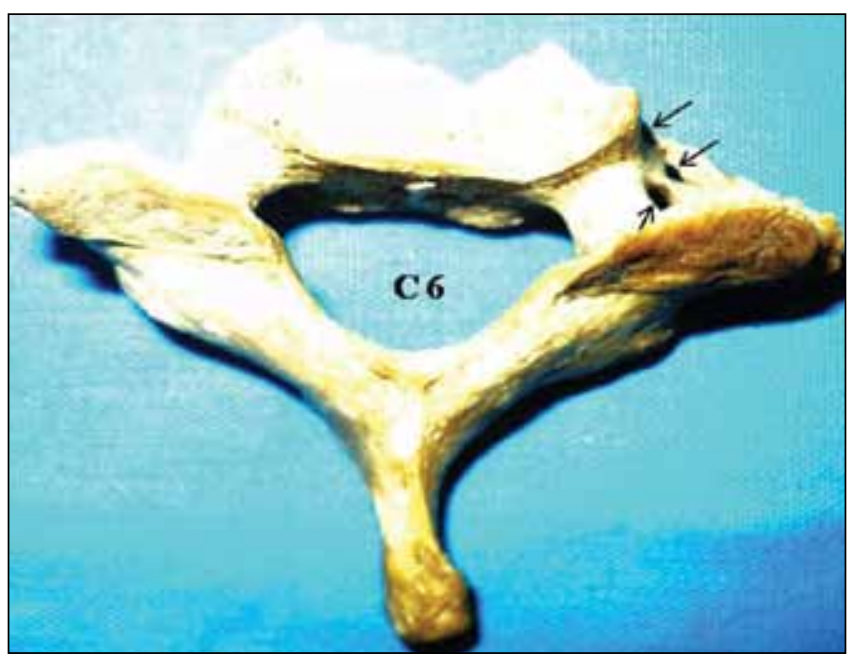

Figure 3: Photograph of C6 cervical spine (superior view) showing triple foramina transversaria $(n=1,0.3 \%)$.

Das et al. (6) from a study of 132 specimens observed the double foramina transversaria unilaterally and bilaterally only in two different cervical vertebras. In contrast, Taitz et al. (14) from their study from 480 cervical vertebras observed the doubling of foramina transversaria in 34 cases. Of these, only 6 vertebrae had foramen transversarium of equal size, while the others had foramina of very small dimensions. They also observed triple foramina transversaria in one vertebrae and absent foramen in 4 cases. In the present study we observed that the accessory foramina were smaller than the usual foramina. We observed double foramina in $1.4 \%$ and triple foramina in $0.3 \%$ of cases. El Shaarawy et al. (7) observed that the accessory foramina transversaria were most common at the lower cervical vertebrae (C5, C6 and C7), mostly in C6. In the present study also the foramina were seen at C6 and C7.

Detailsare notavailable regarding the contents of the accessory foramina in the literature. It is not clear whether one of the foramina is occupied by the artery and the other by veins or each foramen is occupied by branches of vertebral artery and veins. The surgical anatomy of the foramen transversarium and vertebral artery are important to the neurosurgeons and radiologists. Their anatomy and morphology is useful to the operating spine surgeons and radiologists in the interpretation of radiographic films and computed tomogram scans. Maintaining the vertebral artery intact constitutes an important concern during cervical procedures (11) since minor lesions may result in severe hemorrhages or even death. There are anatomical studies undertaken in an attempt to minimize the intraoperative lesions of these arteries $(1,5)$. It should be remembered that the vertebral and basilar arteries contribute to the blood supply not only of the brain, but also the inner ear. Compression or spasm of the vertebral artery is manifested not only by neurological symptoms but also by hearing disturbances (12). 


\section{CONCLUSION}

The present study observed the accessory foramen transversarium in $1.6 \%$ of the cases. A unilateral presence was more common than bilateral and the foramina were observed at the lower cervical vertebrae (C6 and C7). The aetiological factors were explained on an embryological basis. Their morphological knowledge is clinically important since the course of the vertebral artery may be distorted in such situations. The surgical anatomy of these variant foramina is important for the operating surgeons and radiologists when interpreting the computed tomogram and magnetic resonance image scans.

We believe that the present study has provided additional information on the incidence, morphology, embryological basis and surgical importance of these variant foramina. Future implications on the study of this subject include correlation with dissected specimens and angiograms. The clinical studies on this subject can be correlated with the patient history and symptoms.

\section{ACKNOWLEDGEMENTS}

The authors thank Dr. Hemalatha Praveen and Dr. Prashanth K.U. for the valuable assistance in conducting this study.

\section{REFERENCES}

1. An HS, Gordin R, Renner K: Anatomic considerations for platescrew fixation of the cervical spine. Spine 16:548-551, 1991

2. Bergman RA, Thompson SA, Afifi AK, Saadeh FA: Compendium of Human Anatomic Variation. Germany: Urban \& Schwarzenberg, 1988:197

3. Bridwell $\mathrm{KH}$, Anderson PA, Boden SD, Vaccaro AR, Wang JC: What's new in spine surgery. J Bone Joint Surg Am 90: 1609-1619, 2008

4. Caovilla HH, Gananca MM, Munhoz MS, Silva ML, Gananca FF, Silva ML, Munhoz MS, Gananca MM, Caovilla HH: Sindrome cervical. Quadros Clinicos Otoneurologicos Mais Comuns. Sao Paulo: Atheneu, 2000:95-100
5. Cooper PR, Cohen A, Rosiello A, Koslow M: Posterior stabilization of cervical spine fractures and subluxations using plates and screws. Neurosurgery 23:300-306, 1988

6. Das S, Suri R, Kapur V: Double foramen transversaria: An osteological study with clinical implications. Int Med J 12: 311-313, 2005

7. El Shaarawy EAA, Sabry SM, El Gammaroy T, Nasr LE: Morphology and morphometry of the foramina transversaria of cervical vertebrae: A correlation with the position of the vertebral artery. Kasr El Aini Medical Journal [serial online] June 2010. Accessed December 10, 2010

8. Ionete C, Omojola MF: MR angiographic demonstration of bilateral duplication of the extracranial vertebral artery: Unusual course and review of the literature. AJNR 27: 1304-1306, 2006

9. Jovanovic MS: A comparative study of the foramen transversarium of the sixth and seventh cervical vertebrae. Surg Radiol Anat 12:167-172, 1990

10. Kubikova E, Osvaldova M, Mizerakova P, El Falougy $H$, Benuska $\mathrm{J}$ : A variable origin of the vertebral artery. Bratisl Lek Listy 109:28-30, 2008

11. Riew K: Microscope-assisted anterior cervical decompression and plating techniques for multilevel cervical spondylosis. Operative Techniques in Orthopaedics 8:22-33, 1988

12. Romanov VA, Miller LG, Gaevyĭ MD: The effect of the vertebral nerve on circulation in the inner ear (cochlea). Biull Eksp Biol Med 75:10-12, 1973

13. Sim E, Vaccaro AR, Berzlanovich A, Thaler H, Ullrich CG: Fenestration of the extracranial vertebral artery: Review of the literature. Spine 26:139-142, 2001

14. Taitz C, Nathan H, Arensburg B: Anatomical observations of the foramina transversaria. J Neurol Neurosurg Psychiatry 41:170-176, 1978 